Finanse, Rynki Finansowe, Ubezpieczenia nr 2/2016 (80), cz. 1

DOI: $10.18276 /$ frfu.2016.2.80/1-01

s. $5-8$

\title{
Jubileusz prof. zw. dr. hab. Kazimierza Sawickiego
}

\author{
Teresa Kiziukiewicz, Stanisław Hońko \\ Uniwersytet Szczeciński, Instytut Rachunkowości
}

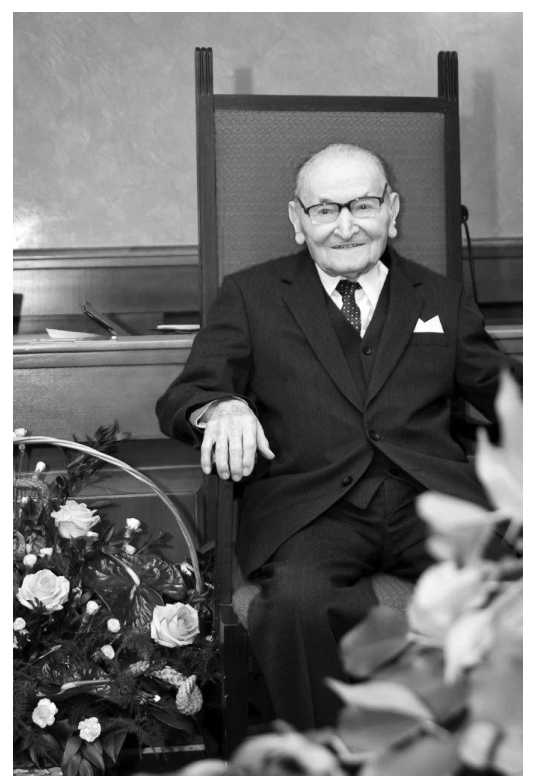

W bieżącym 2016 roku przypada jubileusz - 90-lecia urodzin i 65-lecia pracy naukowej Pana Profesora zw. dr. hab. Kazimierza Sawickiego, doktora honoris causa Uniwersytetu Szczecińskiego. Taki zbieg rocznic jest okazją do przypomnienia drogi zawodowej Szanownego Jubilata.

Pan Profesor Kazimierz Sawicki urodził się 5 marca 1926 roku w Toruniu. Po ukończeniu Liceum Ogólnokształcącego im. Mikołaja Kopernika w Toruniu przeniósł się do Szczecina, aby rozpocząć studia w szczecińskim oddziale Akademii Handlowej w Poznaniu. Istotnym atutem pierwszej na Pomorzu Zachodnim wyższej uczelni ekonomicznej była możliwość łączenia pełnoetatowej pracy zawodowej ze studiami w trybie dziennym. Z szansy tej skorzystał Szanowny Jubilat, który sam siebie nazywa pracusiem. Studiując, jednocześnie pracował w charakterze księgowego i księgowego bilansisty w prywatnych spółkach z o.o. „Kryształ” oraz Odlewni Żeliwa i Metali Kolorowych Przedsiębiorstwa Przemysłu Terenowego w Szczecinie. Zdobyte doświadczenie zawodowe wpłynęło na karierę naukową Pana Profesora, a w rezultacie na historię szczecińskiego ośrodka nauki rachunkowości i rozwój rachunkowości w Polsce.

Po zakończeniu studiów I stopnia 1 grudnia 1950 roku Kazimierz Sawicki został zatrudniony na stanowisku asystenta w Katedrze Rachunkowości Wyższej Szkoły Ekonomicznej w Szczecinie. Ze względu na brak uprawnień rodzimej Alma Mater Pan Profesor zdobywał kolejne stopnie naukowe poza jej murami. W 1952 roku uzyskał magisterium w Wyższej Szkole Ekonomicznej w Łodzi. W 1962 roku na podstawie rozprawy doktorskiej Węzłowe problemy rachunku kosztów w przedsiębiorstwach transportu samochodowego Rada Wydziału Ekonomiki Przedsiębiorstwa Wyższej Szkoły Ekonomicznej we Wrocławiu nadała Kazimierzowi Sawickiemu stopień naukowy doktora nauk ekonomicznych. Po pięciu 
latach, w 1967 roku, uzyskał stopień naukowy docenta nauk ekonomicznych w zakresie rachunkowości na podstawie rozprawy habilitacyjnej Problemy obliczania kosztów jednostkowych przewozów samochodowych. Stopień ten został nadany przez Radę Wydziału Finansów i Statystyki Szkoły Głównej Planowania i Statystyki (obecnie Szkoła Główna Handlowa) w Warszawie. Rozprawa ta w 1968 roku została wyróżniona nagrodą I stopnia przez Radę Naukową Stowarzyszenia Księgowych w Polsce. W 1976 roku Rada Państwa nadała Szanownemu Jubilatowi tytuł profesora nadzwyczajnego, a w 1983 roku - tytuł profesora zwyczajnego nauk ekonomicznych.

Pan Profesor Kazimierz Sawicki jest nie tylko wybitnym naukowcem i dydaktykiem, ale również sprawnym organizatorem. Z zaangażowaniem wielokrotnie piastował ważne stanowiska w Uczelni. Przez ponad 26 lat kierował najpierw Zakładem, a potem Katedrą Rachunkowości. Przez dwie kadencje pełnił także funkcję prodziekana Wydziału Inżynieryjno-Ekonomicznego Transportu Politechniki Szczecińskiej.

Profesor był też aktywnym członkiem kilku organizacji ekonomicznych. Na szczególną uwagę zasługuje Jego wkład w rozwój Stowarzyszenia Księgowych w Polsce, którego członkiem jest od 1957 roku. Warto podkreślić szczególny związek Jubilata ze szczecińskim oddziałem tej organizacji, którego przez wiele lat był prezesem. Za zasługi w 1999 roku Pan Profesor został zaliczony do elitarnego grona 50 członków honorowych Stowarzyszenia Księgowych w Polsce. W 2015 roku został uhonorowany najwyższym odznaczeniem przyznawanym przez Stowarzyszenie - złotą odznaką z diamentem. Pan Profesor przez szereg lat aktywnie uczestniczył również w pracach Krajowej Rady Biegłych Rewidentów, tworząc normy wykonywania zawodu i etyki zawodowej biegłego rewidenta, a także przewodnicząc Komisji Rewizyjnej KIBR. Jednocześnie jako biegły rewident przeprowadzał badania sprawozdań finansowych różnych jednostek gospodarczych. Jest też członkiem Polskiego Towarzystwa Ekonomicznego oraz Szczecińskiego Towarzystwa Naukowego.

Za osiągnięcia w działalności naukowo-badawczej, dydaktycznej i kształcenia kadry naukowej Szanowny Jubilat otrzymał w latach 1969-1980 sześć nagród ministerialnych stopnia I, II i III. Został odznaczony między innymi Krzyżem Kawalerskim Orderu Odrodzenia Polski (1977), Złotym (1973) i Srebrnym Krzyżem Zasługi (1971), Srebrną i Złotą Odznaką „Zasłużony w Rozwoju Stowarzyszenia Księgowych w Polsce” (1966, 1968).

Profesor zadziwia swoich współpracowników niespożytą energią i niezwykłą aktywnością w pracy naukowej i dydaktycznej. Publikowany dorobek Profesora obejmuje dziesiątki monografii, prac zbiorowych, podręczników akademickich, artykułów w czasopismach fachowych oraz w materiałach konferencyjnych. Ponad sześćdziesięcioletni okres pracy naukowej zaowocował imponującą liczbą publikacji trudną do dokładnego określenia, którą można ostrożnie oszacować na ponad 500 pozycji. Pierwsza publikacja Profesora w miesięczniku „Rachunkowość”, której współautorem był nieżyjący już prof. dr hab. Tadeusz Waśniewski, ukazała się w 1960 roku. Zakres tematyczny prac Profesora obejmuje szeroko pojętą rachunkowość, rachunek kosztów, rachunkowość zarządczą, politykę bilansową, analizę finansową, prawo podatkowe, sprawozdawczość i rewizję finansową oraz rachunkowość międzynarodową. Nie tylko interesuje się aktualnymi problemami, ale podejmuje nowe 
obszary badań. Miarą godnej podziwu aktywności Profesora w ostatnim dziesięcioleciu jest liczba opublikowanych prac przekraczająca 150 pozycji.

Profesor swoją wiedzą chętnie dzieli się z zainteresowanymi osobami. Był promotorem 13 rozpraw doktorskich. Cztery Jego doktorantki pracują obecnie w Instytucie Rachunkowości Uniwersytetu Szczecińskiego. Do tego grona należą: prof. zw. dr hab. Teresa Kiziukiewicz, prof. zw. dr hab. Ksenia Czubakowska, prof. zw. dr hab. Kazimiera Winiarska oraz dr Anna Buczkowska. Szanowny Jubilat recenzował ponad 20 rozpraw habilitacyjnych i przeszło 60 prac doktorskich z prawie wszystkich ośrodków akademickich w Polsce. Wśród autorów tych prac znajdują się obecni kierownicy katedr rachunkowości w Szczecinie, Warszawie, Wrocławiu, Toruniu, Poznaniu i Łodzi.

Profesor Kazimierz Sawicki jest przykładem naukowca z powołania, który nie tylko realizuje się jako autor publikacji, ale również jako wszechstronny dydaktyk czerpiący satysfakcję z kontaktu ze studentami. Pan Profesor prowadził zajęcia zarówno na studiach stacjonarnych, jak i niestacjonarnych oraz podyplomowych z różnych przedmiotów, jak na przykład: organizacja rachunkowości i kontroli wewnętrznej, polityka bilansowa, badanie sprawozdań finansowych, rachunkowość holdingów czy rachunkowość jednostek non-profit. Studenci niezmiennie od lat darzą Pana Profesora dużym szacunkiem i sympatią, czego potwierdzeniem była frekwencja na wykładach i wysokie oceny w ankietach wypełnianych przez studentów na koniec semestrów. Obecnie Pan Profesor, mając 90 lat, prowadzi seminaria magisterskie, które są cenione przez uczestniczących w nich studentów. Profesor jest promotorem ponad tysiąca prac magisterskich i licencjackich. Wiele z nich zostało wyróżnionych w konkursach na najlepsze prace z dziedziny nauk ekonomicznych. Warto podkreślić, że każdorazowo w uroczystościach jubileuszowych poświęconych Panu Profesorowi, mimo upływu lat, uczestniczą byli seminarzyści, bardzo ciepło wspominając współpracę z Szanownym Jubilatem.

Tradycyjnie Pan Profesor bierze czynny udział w konferencjach organizowanych przez szczecińską Katedrę, a obecnie Instytut Rachunkowości, przy czym do niedawna był też uczestnikiem konferencji naukowych organizowanych przez inne ośrodki akademickie w Polsce i za granicą. Udział Pana Profesora w konferencjach nie ogranicza się do pełnienia funkcji honorowych. Zasadą jest opracowanie i wygłoszenie referatu przez Pana Profesora oraz aktywny udział w „zajęciach warsztatowych” (pozasesyjnych) - zamiłowanie Jubilata do tańca i niespożyta energia są powszechnie znane.

Kierując Katedrą Rachunkowości Uniwersytetu Szczecińskiego, Pan Profesor utrzymywał ożywione kontakty z uczelniami zagranicznymi. Starał się przy tym włączać do współpracy młodszych pracowników naukowych. Wieloletnia współpraca z Wyższą Szkołą Transportu w Dreźnie zaowocowała wspólnymi projektami badawczymi, organizacją konferencji, których rezultatem były publikacje w Zeszytach Naukowych naszej uczelni i uczelni zagranicznej. Ponadto warto podkreślić współpracę z uczelniami w Wismarze i w Rostocku, gdzie Profesor kilkakrotnie prowadził wykłady. Poza Niemcami Profesor wykładał też w Szkocji, Austrii, Holandii, Bułgarii i na Węgrzech. Dzięki temu Szanowny Jubilat jest znany nie tylko w Polsce. 
Zasługą Profesora Kazimierza Sawickiego jest istotny wkład w rozwój nauki i praktyki rachunkowości. Przyczynił się On do przygotowania fachowych kadr, a także prowadził projekty badawcze. Ponadto jako biegły badał sprawozdania finansowe jednostek gospodarczych.

Szanowny Jubilat jest symbolem Szkoły Rachunkowości Uniwersytetu Szczecińskiego, z którą jest związany niemal od samego początku. Swoją sumienną pracą i zaangażowaniem przyczyniał się i nadal przyczynia do jej rozwoju. Można przyjąć, że obok prof. Eufemiusza Terebuchy Kazimierz Sawicki jest twórcą szczecińskiego ośrodka nauki rachunkowości.

Postawa Szanownego Jubilata jest dla pracowników Instytutu Rachunkowości przykładem, że nauka jest pięknym obowiązkiem, który należy spełniać przez całe życie. Dla Pana Profesora jest ona źródłem energii, z której zdaje się czerpać też radość i optymizm. Profesor Kazimierz Sawicki jest legendą polskiej rachunkowości. Dla współpracowników stanowi wzór uczonego i człowieka, który mimo imponujących osiągnięć jest skromny, otwarty i życzliwy. Jego życiorys jest przykładem realizacji rzymskiej maksymy, że człowiek pracowity nigdy się nie nudzi, ponieważ zawsze ma coś do zrobienia. Jednocześnie Pan Profesor potrafi znaleźć równowagę między pracą i wypoczynkiem, pasjonując się turystyką, grą w szachy i brydża.

Zaprezentowany w dużym skrócie dorobek naukowy, dydaktyczny i organizacyjny Pana Profesora jest znaczący. Nadal tworzy On nowe dzieła, uczestniczy w konferencjach naukowych, prowadzi seminaria. Osiągnął rzadko spotykane rezultaty jako uczony, dydaktyk i praktyk. Wyrazem uznania dla Jego zasług i wkładu w rozwój nauki i praktyki rachunkowości było w 2006 roku nadanie Panu Profesorowi przez Senat Uniwersytetu Szczecińskiego godności doktora honoris causa, który jest honorowym stopniem naukowym nadawanym przez wyższe uczelnie osobom szczególnie zasłużonym na polu nauki. Warto podkreślić, że był to drugi w Polsce stopień doktora honoris causa w rachunkowości jako dyscyplinie nauki. 